\title{
Online Learning as Teaching - Learning Pedagogy in B.ED. Colleges
}

Yusra Farooqui ( $\nabla$ yusrafarooqui009@gmail.com )

Aishabai College of Education

Darshana Shah

Aishabai College of Education

Dr. Rabiya Saboowala

Aishabai College of Education https://orcid.org/0000-0002-0008-5599

\section{Research Article}

Keywords: Online Learning, COVID-19 pandemic, Prospective teachers

Posted Date: April 14th, 2021

DOl: https://doi.org/10.21203/rs.3.rs-410201/v1

License: (c) (i) This work is licensed under a Creative Commons Attribution 4.0 International License. Read Full License 


\section{Abstract}

In the 21 st century, the attainment of knowledge and education goes far beyond the boundaries of educational institutions. Learning takes place in many diversified forms, be it in form of location or time or course content. This makes it easy to facilitate learning across the globe with ease so that the learners can pursue what they wish to. Among these various diversified and facilitated forms of learning, the most adopted and acceptable way of promoting academics in reputed educational setup undoubtedly is online learning. The concept of online learning has been implemented in all educational sectors throughout the globe due to the prevailing COVID-19 pandemic. The present action research aimed at examining the attitudes of second year Prospective teachers who are working as well as those who are not working towards online learning during the prevailing pandemic in Mumbai. A questionnaire with 5-point Likert scale was adopted for data collection from a sample of 54 prospective teachers. Findings of the study reveal the working prospective teachers have a higher attitude towards adopting online learning as teaching-learning pedagogy for B.Ed. teachers as compared to non-working Prospective teachers. Also, working Prospective teachers had a higher attitude towards Computer/Internet self-efficacy, Self-directed learning and Online communication self-efficacy dimension of online learning when compared with nonworking Prospective teachers. Not-Working B.Ed. Teachers had a higher attitude towards the Learner Control dimension of online learning, whereas both working and non-working Prospective teachers had a similar attitude towards Motivation for learning (in an online context) dimension of online learning. Policy makers should include online learning topics in the B.Ed. curriculum not just theoretically but also practically in order to help learners develop a positive attitude towards adoption of online learning not just for learning but also for teaching. Also, the government and educational institutes need to organize workshops and seminars for teachers and student-teachers in order to equip them with knowledge and application of computers in the academic process which is the need of the hour during the prevailing pandemic.

\section{Introduction}

Many studies done throughout the globe have demonstrated that learner's involvement in the learning process actively helps in enhancing their learning, a process which is often referred to as active learning (Benek-Rivera and Matthews, 2004; Sarason and Banbury, 2004). In other words, active learning involves those instructional activities which involve students in doing things actively and also help them think about what they are doing (Bonwell and Eisen, 1991, p. 5). Positive learning outcomes have been found if taught through Interactive instruction or "learning by doing" (Picciano, 2002; Watkins, 2005). Many new technologies have been developed and web-based activities are considered interactive, online learning environment has the potential to create atmosphere where students can actively be engaged with content material and learn by doing at their pace, refining their understanding simultaneously as they build new knowledge (Johnston, Killion and Omomen, 2005; Pallof and Pratt, 2003).

Some students who do not have reliable internet access or no proper access to technology struggle to participate in online learning; this gap is seen across countries even in India. For example, according to 
OECD data whilst 95\% of students in Switzerland, Norway, and Austria have a computer to use for their schoolwork, only $34 \%$ in Indonesia do (Li and Lalani, 2020). Built upon a foundation of learning theory, online learning can potentially provide many important payoffs. Online instruction to the learners offers the flexibility in terms of pace and time and convenience to complete learning units and content when and where a learner desires. Along with this, online education has been cost effective and to provide an efficient, standardized way to deliver content (McDonald, 1999-2000; "E-learning," 2003; "The Pay-offs," 2003). Additionally, to potential cost savings, online learning has pedagogical potential far beyond traditional methods when related to the principles of learning as discussed earlier. Online learning can deliver "novel" information efficiently and effectively reinforcing other course information through offering examples, explanations, assessments, and exercises. In this way, online instruction is predicted to potentially enhance learning outcomes and achieve learning objectives when compared to what can be accomplished using a traditional classroom only approach (McEwen, 1997).

However, there are also potential disadvantages or limitations of online learning. For example, one study concluded that only online learning was not effective as a standalone method to deliver content and information as students do require face to face guidance as well. (Laine, 2003). The present study takes into consideration the attitude of student teachers towards online learning as the teaching-learning pedagogy.

\section{Background Of The Study}

Al-Fahad (2009) concluded from his research that students extensively got accustomed to m-learning (mobile learning) because for them to search, gain and work independently on learning materials and resources in less time, it was much easier with wireless networks. The finding of Woo (2000:132-139) studies showed that discussions about adoption of online learning have not been fruitful rather it was time consuming and difficult. This also coincide with the attitudes towards online learning, Warnet, et.al. (2000:487-504) conducted a research on students, where it was found that they were frequently using Web CT in the course of social work, proclaimed that majority of the respondents had predetermined ideas about the course material of online learning, which was beneficial to their learning experience in summation. Similarly, Sanders (2002:251-262) assessed the students' attitude regarding enabling of learning components through the Web in the course of biology at tertiary level. Findings of the study revealed that the web component had a highly positive impact on the learning of students' with reference to their problem solving approach and development of critical thinking abilities.

A quantitative study was conducted by Yang (2006) in order to explore attitudes towards web-based distance learning and found positive attitudes of students toward online learning because of the feasibility and new ways of learning. In yet another study, the attitude of nursing students towards online learning technology at the Open University in the United Kingdom, a survey was conducted by Kirkwood (2003: 155-176). Here the findings of the study showed strong affirmation of student's attitude regarding the application of multimedia technologies in online learning. However the findings of the study showed 
strongly positive students' attitudes regarding the application of multimedia technologies in online learning.

In some past research studies the negative attitudes of students towards online learning were also found. The negative attitudes of students towards online learning were reflected with low level of computer skills, technological anxiety, and computer hardware problems, as well as poor study skills, low motivation, and an inability to work independently (Smith, et.al. 2000:59-81, Govindasamy, 2001; Rosenberg, 2001). Personal contact with the teacher and peer in class was lacking which another negative factor is regarding online learning. Isolation and loneliness were some of the feelings students had when they were required to face a computer screen. (Ponzurick, et. al, 2000:180-187).

\section{Methodology, Tool And Sample Of The Study}

A descriptive survey was adopted for the present action research in order to study the attitude of working and not-working Prospective students towards adopting online learning as the teaching-learning pedagogy. The tool for online learning was adopted from Hung et al. 2010. The questionnaire consisted of 18 items scored on 5 point likert scale divided into 5 constructs of online learning viz. Computer/Internet self-efficacy item 1-3, Self-directed learning item 4-8, Learner Control item 9-11, Motivation for learning (in an online context) item 12-15 and Online communication self-efficacy item $16-20$.

The available sample was used for collecting data through Google forms. The sample consisted of 54 students studying in second year B.Ed colleges from Mumbai. Out of 54 Prospective teachers, 39 were not working and 15 were working in educational institutes. Table 1.1 below represents the sample size for the present study.

Table 1.1

Sample size for the Present Study

\begin{tabular}{|lll|}
\hline & Number of students & Percentage (\%) \\
\hline All Students & 54 & 100 \\
\hline Working & 15 & 27.8 \\
\hline Not working & 39 & 72.2 \\
\hline
\end{tabular}

Figure 1.1 is a pie chart representing the data for present study in percentage. Out of the total S.Y. B.Ed. Prospective teachers $72.2 \%$ were not working and $27.8 \%$ were working in Educational Institute.

\section{Aim Of The Present Study}

To study the attitude of working and not-working prospective teachers towards adopting Online Learning as the teaching-learning pedagogy in B.Ed. Colleges 


\section{Hypothesis Testing And Interpretation Of Data}

The following hypotheses were framed and tested using relevant statistical analysis.

\section{Hypothesis 1}

There is no significant difference in the attitude of prospective teachers towards adopting online learning as the teaching-learning pedagogy in B.Ed. colleges.

Table 1.2

Relevant Descriptive Statistics for Testing Hypothesis 1

\begin{tabular}{|lccccccc|}
\hline & N & Mean & Median & Mode & S.D & Skewness & Kurtosis \\
\hline Total Prospective Teachers & 54 & 72.14 & 72 & 78 & 6.02 & -0.32 & -0.73 \\
\hline Working Prospective Teachers & 15 & 75.13 & 77 & 78 & 4.15 & -0.75 & -1.03 \\
\hline $\begin{array}{l}\text { Not-Working Prospective } \\
\text { Teachers }\end{array}$ & 19 & 71 & 71 & 68 & 6.27 & -0.03 & -0.76 \\
\hline
\end{tabular}

The Mean value for prospective teachers was found to be 72.14 , Median value was found to be 72 , Mode value was found to be 78 and Standard Deviation was found to be 6.02. The distribution is negatively skewed. The skewness is found to be -0.32 . The kurtosis is found to be -0.73 which is negative. Thus, distribution is platykurtic by nature.

The Mean value for working prospective teachers was found to be 75.13 Median value was found to be 77 , Mode value was found to be 78 and Standard Deviation was found to be 4.15. The skewness is found to be -0.75 which is negative. The kurtosis is found to be -1.03 which is negative. Thus, the distribution is platykurtic by nature.

The Mean value for not working prospective teachers was found to be 71 , Median value was found to be 71.00 , Mode value was found to be 68 and Standard Deviation was found to be 6.27 . The skewness was found to be -0.03 which is negative. The kurtosis was found to be -0.76 which is negative. Thus, the distribution is platykurtic by nature.

\section{Hypothesis 2}

There is no significant difference in the attitude of working and not-working prospective teachers towards adopting online learning as the teaching-learning pedagogy in B.Ed. colleges. 
Table 1.3

Inferential Analysis Data for testing Hypothesis 2

\begin{tabular}{|llllll|}
\hline Group & N & Mean & t ratio & p value & LoS \\
\cline { 1 - 4 } Working & 15 & 137.00 & 1.98 & 0.04 & S \\
\cline { 1 - 3 } not working & 39 & 130.82 & & & \\
\cline { 1 - 3 } & & & & \\
\hline
\end{tabular}

The $t$ ratio for the attitude of working and non-working prospective teachers towards adopting online learning as the teaching-learning pedagogy in B.Ed. College was found to be 1.98. The $p$ value was found to be 0.04 which is less than 0.05 , thus it is significant. Hence, the null hypothesis is rejected. Therefore there is a significant relationship between the attitude of working and not-working prospective teachers towards adopting online learning as the teaching-learning pedagogy in B.Ed. colleges. The mean score of working prospective teachers is 137 which is greater than the mean score of non-working prospective teachers. This indicates that working prospective teachers have a higher attitude towards adopting online learning as the teaching-learning pedagogy as compared to not-working prospective teachers.

\section{Hypothesis 3}

There is no significant difference in the attitude of working and not-working prospective teachers towards adopting online learning and its following dimensions as the teaching-learning pedagogy in B.Ed. colleges:

- Computer/Internet self-efficacy

- Self-Directed Learning

- Learner Control

- Motivation for Learning (in an online context)

- Online Communication Self-Efficacy 
Table 1.4

Inferential Analyses to Test Hypothesis 3

\begin{tabular}{|c|c|c|c|c|c|c|}
\hline Dimensions & Group & $\mathbf{N}$ & Mean & $\begin{array}{l}\mathrm{t} \\
\text { ratio }\end{array}$ & $\mathrm{p}$ value & LoS \\
\hline \multirow[t]{2}{*}{ Computer/Internet self-efficacy } & Working & 15 & 14.13 & \multirow[t]{2}{*}{2.27} & \multirow[t]{2}{*}{0.027} & \multirow[t]{2}{*}{ S } \\
\hline & $\begin{array}{l}\text { Not } \\
\text { working }\end{array}$ & 39 & 12.97 & & & \\
\hline \multirow[t]{2}{*}{ Self-directed learning } & Working & 15 & 22.66 & \multirow[t]{2}{*}{3.10} & \multirow[t]{2}{*}{0.003} & \multirow[t]{2}{*}{$S$} \\
\hline & $\begin{array}{l}\text { Not } \\
\text { working }\end{array}$ & 39 & 20.41 & & & \\
\hline \multirow[t]{2}{*}{ Learner control } & Working & 15 & 09.00 & \multirow[t]{2}{*}{2.29} & \multirow[t]{2}{*}{0.026} & \multirow[t]{2}{*}{ S } \\
\hline & $\begin{array}{l}\text { Not } \\
\text { working }\end{array}$ & 39 & 10.12 & & & \\
\hline \multirow{2}{*}{$\begin{array}{l}\text { Motivation for learning (in an online } \\
\text { context) }\end{array}$} & Working & 15 & 16.06 & \multirow[t]{2}{*}{0.42} & \multirow[t]{2}{*}{0.676} & \multirow[t]{2}{*}{ NS } \\
\hline & $\begin{array}{l}\text { Not } \\
\text { working }\end{array}$ & 39 & 16.30 & & & \\
\hline \multirow[t]{2}{*}{ Online communication self-efficacy } & Working & 15 & 13.26 & \multirow[t]{2}{*}{3.30} & \multirow[t]{2}{*}{0.001} & \multirow[t]{2}{*}{$S$} \\
\hline & $\begin{array}{l}\text { Not } \\
\text { working }\end{array}$ & 39 & 11.17 & & & \\
\hline
\end{tabular}

The t- value for attitude of working and not working prospective teachers towards computer/internet selfefficacy, Self directed learning and Online communication self-efficacy dimension of online learning was found to be 2.27, 3.10 and 3.30 respectively. The $p$ value for computer/internet self-efficacy was found to be 0.02 which is less than 0.05 , thus it is significant. Also, the $p$ value for Self directed learning and Online communication self-efficacy dimension of online learning was found to be 0.003 and 0.001 respectively which is less than 0.01 , thus it is significant. Also, for all the above 3 dimensions of online learning the mean scores for working prospective teachers was higher. Thus the null hypothesis is rejected with respect to computer/internet self-efficacy, self directed learning and Online communication self-efficacy dimension of online learning. The attitude of working prospective teachers towards adopting computer/internet self-efficacy, self directed learning and Online communication self-efficacy dimension of online learning as teaching-learning pedagogy in B.Ed. colleges were higher as compared to those prospective teachers who were currently not working.

The t- value for attitude of working and non-working prospective teachers towards adopting online learning as the teaching-learning pedagogy in B.Ed. colleges was found to be 2.29 with regards to Learner Control dimension. The $p$ value for the same was found to be 0.026 which is less than 0.05 , thus it is significant. Therefore, the null hypothesis is rejected. The mean score of not-working prospective teachers was found to be 10.12 which is greater than the mean scores of working prospective teachers. Thus, non 
working prospective teachers have a higher attitude towards adopting online learning as the teachinglearning pedagogy as compared to working teachers in terms of Learner control dimension.

The $t$ - value for attitude of working and not-working prospective teachers adopting online learning as the teaching-learning pedagogy in B.Ed. colleges was found to be 0.42 with regards to motivation for learning (in online context) dimension. The $p$ value was found to be 0.676 which is more than 0.05 , thus it is not significant. Therefore, the null hypothesis is accepted. This indicates that working prospective teachers and not-working teachers have a similar attitude towards adopting online learning as the teachinglearning pedagogy in terms of motivation for learning (in online context) dimension.

\section{Discussion And Conclusion}

Online learning is no more a new concept but not all educational institutes including B.Ed. colleges have adopted this pedagogy solely. The current pandemic of COVID-19 has added fuel to fire where the only option left to impart knowledge is through online learning. The teacher training institutes have also adopted online-pedagogy for teaching and learning, Internet connectivity issues, lack of training and infrastructure, age, gender, computer experience, technology acceptance and individual learning styles are few key factors that need to be considered while examining the pupil's point of view regarding online learning systems. Due to the current lockdown all over the globe, even in India the teacher training institutes have adopted online learning at least till the time the crisis is on. Understanding the need for online learning as the teaching-learning pedagogy, the researcher adopted the attitude of prospective teachers towards the same.

The results of this action research study highlighted that the working status of prospective teachers had an impact on their attitude towards adopting online learning as the teaching-learning pedagogy in B.Ed. colleges. Also, the dimensions of online learning that were considered viz. Computer/Internet self-efficacy, Self-directed learning, Learner Control, and Online communication self-efficacy were affected by the working status of prospective teachers. Motivation for learning (in an online context) dimension of online learning remained unaffected. Currently, it was noticed that the prospective teachers along with learning, few of them were already teaching in educational institutes. Their exposure towards the teaching-learning process is presumed to be more than those who are not-working. The prospective teachers who are teaching and are pursuing their degrees simultaneously have played the role of teachers as well as learners compared to those who are just pursuing their degree and not working who have just experienced their roles as learners and not as teachers.

The results obtained from this research were contradictory to the results obtained by Al-Fahad (2009) where working and not working students developed skills to the same extent. Here, there was a difference in attitude based on prospective teachers working status. The working prospective teachers took more responsibilities towards the learning context to reach in order to achieve their learning objectives, they also possessed better learning ability to demonstrate proper computer and Internet skills and also were adapted to the online setting through questioning, responding, commenting and discussing as compared 
to those who were not working. The working prospective teachers are more confident while using technology as they are well-versed with it due to their teaching process in schools or colleges; they have been more exposed to such online platforms which not-working prospective teachers are not exposed to. Thus the difference in attitude was observed in the Computer/Internet self-efficacy, Self-directed learning, Learner Control and Online communication self-efficacy dimensions of online learning. On the other hand, not-working teachers control over their learning to direct their own learning with maximum freedom. They were comfortable to skip or manifest the learning content as per their freedom, which working prospective teachers were unable to do. Working teachers learn with the aim in mind that missing a particular content may not be important to them while learning, but can be useful while teaching. Motivation levels among working and not-working teachers were the same while considering online learning.

The education system in India especially the B.Ed. curriculum is based on traditional and physical classroom education that requires the students to attend the classes every day. The COVID-19 pandemic outbreak has been a game-changer in the way pedagogy is happening around the world. Online earning has received an overwhelming response during these closures. The main aim of the education system is life-long learning, where the process of teaching-learning never ends irrespective of the situation. In other words, online learning is a way of combating the spread of a communicable virus like COVID-19 and also, has helped in following norms laid by the government. More and more training programs, webinars, conferences pertaining to online learning should be organized by educational institutes, educational ministry in order to help and equip teachers to deal with their problems faced during teaching-learning. Policy makers should also consider online learning as an important content in curriculum design not only theoretically but practically as well.

\section{Declarations}

\section{Disclosure of potential conflicts of interest:}

The authors state that there are no conflicts of interest.

\section{References}

Benek-Rivera, J., and Matthews, V.E. (2004). Active learning with jeopardy: Students ask the questions. Journal of Management Education, 28, 104-118.

Bonwell, C.C., and Eisen, J.A. (1991). Active learning: Creating excitement in the classroom (ASHE-ERIC Higher Education Report No. 1). Washington, DC: George Washington University

Fahad, A., N., F. (2009). Students' Attitudes and Perceptions towards the Effectiveness of Mobile Learning in King Saud University, Saudi Arabia. The Turkish Online Journal of Educational Technology- TOJET, $8(2), 111-119$

Govindasamy, T. (2001). Successful Implementation of e-learning: Pedagogical Considerations. The Internet and Higher Education. 4(3-4), 287-299. 
Johnston, J., Killion, J., and Oomen, J. (2005). Student satisfaction in the virtual classroom. The Internet Journal of Allied Health Sciences and Practice. 3. Available January 26, 2006, at http://ijahsp.nova.edu/articles/vol3num2/Johnston\%20-\%20Printer\%20Version.pdf

Kirkwood, A. (2003). Understanding independent learners' use of media technologies. Open Learning $18(2), 155-176$.

Laine, L. (2003). Is e-learning effective for IT training? T +D, 57(6), 55-60.

McDonald, D. (1999-2000). Improved training methods through the use of multimedia technology. Journal of Computer Information Systems, 40(2), 17-20.

McEwan, B. (2001). Web-assisted and online learning. Business Communications Quarterly, 64(2), 98103.

Moawad, R.A. (2020). Online Learning during the COVID- 19 Pandemic and Academic Stress in University Students. Revista Romaneasca pentru Educatie Multidimensionala, 12(1Sup2), xx-xx.

https://doi.org/10.18662/rrem/12.1sup1/

Pallof, R., and Pratt, K. (2003). The Virtual Student: A Profile and Guide to Working with Online Learners. San Francisco, CA: Josey-Bass Publishers

Paris, P. G. (2004) Online learning: A Study on Secondary Students' Attitudes towards Online WebAssisted Learning, International Education Journal. 5(1), 98-112.

Ponzurick, T. G., France, K., Russo, L., and Cyril, M. (2000). Delivering graduate marketing education: An analysis of face-to-face versus distance education. Journal of Marketing Education. 22(3), 180-187.

Picciano, A.G. (2002). Beyond student perceptions: Issues interaction, presence, and performance in an online course. Journal of Asynchronous Learning Networks, 6, 20-41.

Sanders, D. W. and Morrison-Shetlar, A. I. (2002). Student Attitudes toward WebEnhanced Instruction in an Introductory Biology Course. Journal of Research on Computing in Education, 33(3), 251-262.

Sarason, Y. and Banbury, C. 2004. Active learning facilitated by using a game-show format or who doesn't. Journal of Management Education; 28 (4), 509-518.

Smith, B., Caputi, P., and Rawstorne, P. (2000). Differentiating computer experience and attitudes toward computers: an empirical investigation. Computers in Human Behavior, 16, 59-81.

The pay-offs of e-learning go far beyond the financial. (2003). HR Focus, 80(10), 7-9.

Warnet, S., Olliges, R., and Delicath, T. (2000). "Post course Evaluations of WebCT Classes by Social Work Students", Research on Social Work Practice, 10(4), 487- 504 
Watkins, R. (2005). Developing interactive e-learning activities. Performance Improvement, 44, 5-7

Woo, M.A., and Kimmick, J.V. (2000). Comparison of Internet versus lecture instructional methods for teaching nursing research. Journal of Professional Nursing. 16, 132-139.

Yang, K.F. Yu, S., (2006). Attitude toward web based distance learning amongst public health nurses in Taiwan: A questionnaire survey. International Journal of Nursing Studies, 43(6), 767-74.

\section{Figures}

\section{Sample Size}

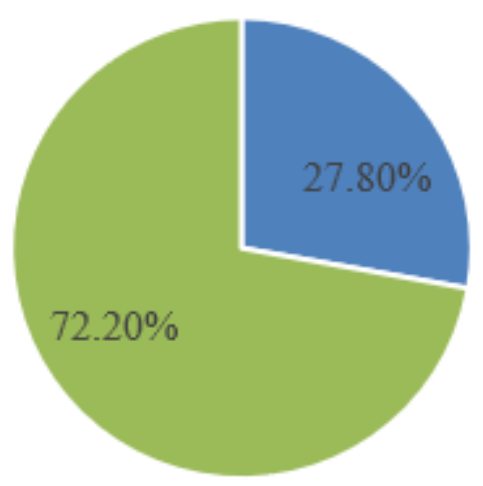

- Working Prospective Teachers " Not Working Prospective Teachers

Figure 1.1 Pie Chart depicting Sample Size

\section{Figure 1}

Pie Chart depicting Sample Size 